\title{
One new compound from Borreria alata (Aubl.) DC (Rubiaceae) in Vietnam
}

- To Cam Loan

An Giang University

- Pham Nguyen Kim Tuyen

Sai Gon University

- Nguyen Kim Phi Phung

University of Science, VNU-HCM

(Received on July $09^{\text {th }} 2015$, accepted on March $29^{\text {th }}$ 2016)

\begin{abstract}
Borreria is a genus of Rubiaceae widespread in tropical and subtropical America, Africa, Asia, and Europe. Studies have confirmed that extracts as well as some isolated compounds of species of Borreria genus possess diverse biological activities, including anti-inflammatory, antitumor, antimicrobial, antioxidant, anti-ulcer... In this paper, we present the chemical structures of four compounds isolated from Borreria alata, collected at Di Linh district, Lam

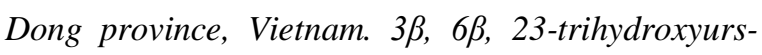
12-en-28-oic acid (1), sodium deacetylasperulosidate (2), 7ß-hydroxy-11-methylforsythide (3) and sodium loganate (4). Among them, three compounds (1), (2), (3) were known for the first time in Borreria genus to our best knowledge and (4) is a new compound. The chemical structures of these compounds wereelucidated by analysis of $1 D$ and $2 D N M R$ and HR-MS spectroscopic data, as well as by comparison with those reported in the literature.

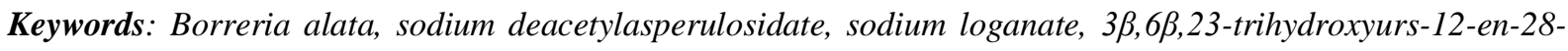
oic acid,7ß-hydroxy-11-methylforsythide.

\section{INTRODUCTION}

Borreria alata (Aubl.) DC. (synonym: Spermacoce alata Aubl., B. latifolia K. Schum.) belongs to the Rubiaceae family [2]. In Nepal, the roots juice of Borreria alata is used to treat malaria [3]. There was only one paper that reported the isolation of eight compounds from B. alata growing in Indonesia [4]. In Vietnam, B. alata is a wide weed in coffee gardens and there has not yet been chemically studied.

Because phytochemicals depends on phenotypic and genotypic factors, the aim of this study was to investigate the chemical constituents of Borreria alata growing in Vietnam. In this paper, we described the isolation and structural elucidation of a new compound (4), together with three known ones (1 3). 


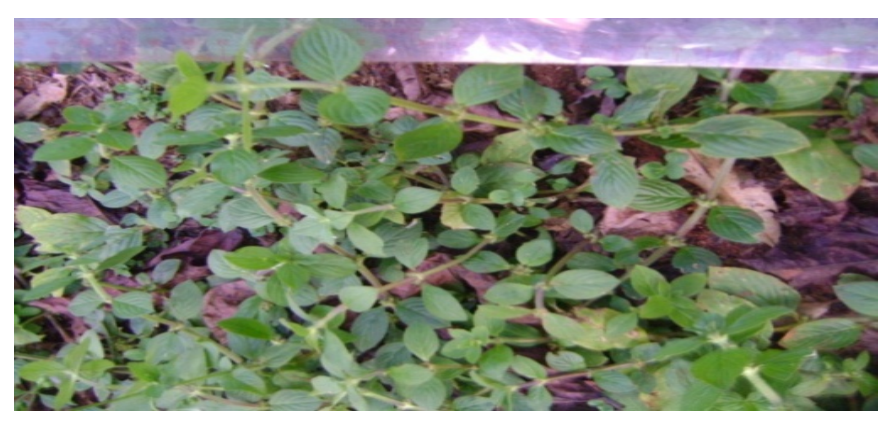

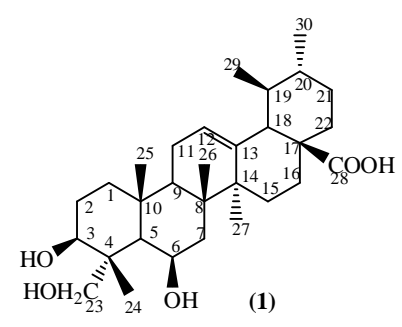

(1)

Fig. 1. Borreria alata (Aubl.) DC. collected at Lam Dong province.
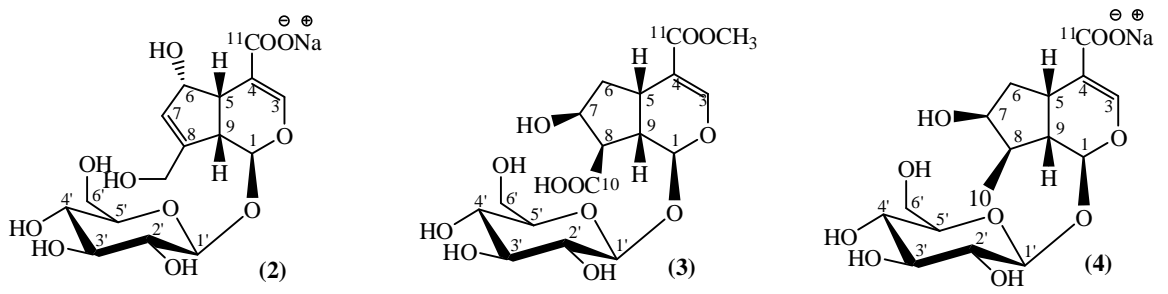

Fig. 2. Chemical structures of isolated compounds

\section{METERIALS AND METHODS}

\section{General}

NMR spectra were recorded on a Bruker Avance 500 (500 MHz for ${ }^{1} \mathrm{H}$ NMR and $125 \mathrm{MHz}$ for ${ }^{13} \mathrm{C} \mathrm{NMR}$ ) and HR-ESI-MS spectra were recorded on Bruker micrOTOF Q-IImass spectrometer. All the instruments are in the Center of Analysis, University of Science, VNU- HCM.

\section{Plant materials}

The whole plant of Borreria alata was collected at Lam Dong province, Viet Nam in November 2012. The scientific name was authenticated by the botanist Vo Van Chi. A voucher specimen (No US-C031) was deposited at the herbarium of the Department of Organic Chemistry, University of Science, VNUHCM.

\section{Extraction and isolation}

The whole plant (40 kg) was washed, dried and ground into powder $(6 \mathrm{~kg})$. This powder was extracted with methanol at room temperature and then the methanol extract was evaporated in reduced pressure to give a methanol residue $(290 \mathrm{~g})$. The residue was dissolved in solvent systems of methanol: water (1:9), then was partitioned against $n$-hexane, chloroform, ethyl acetate and methanol, respectively. The obtained solutions were evaporated to afford corresponding extracts: hexane ( $\mathrm{H}, 120.5 \mathrm{~g})$, chloroform (C, 15.3g), ethyl acetate (EA, $20.0 \mathrm{~g})$, methanol (M, $76.5 \mathrm{~g})$ and aqueous $(35.7 \mathrm{~g})$. The $\mathrm{C}$ extract ( $15.3 \mathrm{~g}$ ) was subjected to silica gel CC eluting with a solvent system of $n$-hexane-ethyl acetate (stepwise, 10:0 to 0:10) to yield five fractions (C1-C5). Fraction C5 (2.1 g) was applied to C-18 silica gel $\mathrm{CC}$ and was eluted with solvent system of water:methanol (stepwise, 100:0 to 0:100) to obtain four subfractions (C5.1-C5.5). The silica gel CC on subfraction C5.3 (0.3 g) afforded (1) (15 mg). The M extract $(76.5 \mathrm{~g}$ ) was subjected to $\mathrm{C}-18$ silica gel $\mathrm{CC}$ eluting with a solvent system of water : methanol (stepwise, 100:0 to 0:100) to yield eight fractions (M1-M8). Fraction M6 (4.2 g) was applied to silica gel CC and was eluted with solvent system of ethyl acetate:methanol:water (stepwise, 80:20:2 to 70:30:5) to obtain five subfractions (M6.1-M6.5). The silica gel CC on subfraction M6.2 (0.7 g) afforded (2) (4 $\mathrm{mg}$ ) and (4) (3 mg) and on subfraction M6.3 (0.7 g) afforded (3) (6 mg). 
$3 \beta, 6 \beta, 23$-Trihydroxyurs-12-en-28-oic acid (1). White powder. ${ }^{1} \mathrm{H}$ NMR (DMSO- $\left.d_{6}\right): 3.42$ (1H, $d d, J=9.5 / 5.0$ $\mathrm{Hz}, \mathrm{H}-3), 4.08(1 \mathrm{H}, d, J=5.0 \mathrm{~Hz}, 3-\mathrm{OH}), 1.09(1 \mathrm{H}, m, \mathrm{H}-5), 4.30(1 \mathrm{H}, m, \mathrm{H}-6), 3.99(1 \mathrm{H}, d, J=3.0 \mathrm{~Hz}, 6-\mathrm{OH})$, $5.19(1 \mathrm{H}, t, J=3.0 \mathrm{~Hz}, \mathrm{H}-12), 2.15(1 \mathrm{H}, d, J=11.5 \mathrm{~Hz}, \mathrm{H}-18), 3.27(1 \mathrm{H}, d, J=5.0 \mathrm{~Hz}, \mathrm{H}-23 \mathrm{a}), 3.41(1 \mathrm{H}, d, J=4.5$ $\mathrm{Hz}, \mathrm{H}-23 \mathrm{~b}), 4.29$ (1H, m, 23-OH), 0.93 (3H, s, H-24), 1.26 (3H, s, H-25), 1.03 (3H, s, H-26), 1.03 (3H, s, H-27), $11.9(1 \mathrm{H}, s, \mathrm{H}-28), 0.85(3 \mathrm{H}, d, J=6.5 \mathrm{~Hz}, \mathrm{H}-29)$ and $0.94(3 \mathrm{H}, d, J=6.0 \mathrm{~Hz}, \mathrm{H}-30) .{ }^{13} \mathrm{C}$ NMR (DMSO- $\left.d_{6}\right): \delta_{\mathrm{C}}$ 40.2 (C-1), 26.7 (C-2), 70.5 (C-3), 42.6 (C-4), 46.9 (C-5), 65.9 (C-6), 39.7 (C-7), 38.2 (C-8), 47.3 (C-9), 35.7 (C10), 22.8 (C-11), 124.9 (C-12), 137.6 (C-13), 42.1 (C-14), 27.5 (C-15), 23.4 (C-16), 46.8 (C-17), 52.4 (C-18), 38.4 (C-19), 38.5 (C-20), 30.2 (C-21), 36.3 (C-22), 64.2 (C-23), 13.8 (C-24), 17.0 (C-25), 18.0 (C-26), 23.8 (C27), 178.2 (C-28), 16.8 (C-29) and 21.0 (C-30).

Sodium deacetylasperulosidate (2). Colorless amorphous powder. HR-ESI-MS (positive ion mode) $m / z:[\mathrm{M}+\mathrm{Na}]^{+}$calcd. for $\mathrm{C}_{16} \mathrm{H}_{21} \mathrm{O}_{11} \mathrm{Na}+\mathrm{Na}$ : 435.0880, found 435.0859; and $[\mathrm{M}+\mathrm{H}]^{+}$calcd. for $\mathrm{C}_{16} \mathrm{H}_{21} \mathrm{O}_{11} \mathrm{Na}+\mathrm{H}$ : 413.1060, found 413.1037. ${ }^{1} \mathrm{H}$ NMR (CD $\left.{ }_{3} \mathrm{OD}\right): 4.98$ (d, J=9.0 Hz, H-1), 7.42 (br s, H-3), 3.04 ( $m, \mathrm{H}-5$ ), 4.89 ( $m$, H-6), 5.98 ( $b r s, \mathrm{H}-7), 2.53$ ( $t, J=8.0 \mathrm{~Hz}, \mathrm{H}-9), 4.44$ ( $b r d, J=15.5 \mathrm{~Hz}, \mathrm{H}-10 \mathrm{a}), 4.21$ (d, J=15.5 Hz, H-10b), 4.71 $\left(d, J=8.0 \mathrm{~Hz}, \mathrm{H}-1^{\prime}\right), 3.22$ ( $\left.m, \mathrm{H}-2^{\prime}\right), 3.27$ ( $m, \mathrm{H}-3$ ') 3.25 ( $\left.m, \mathrm{H}-4^{\prime}\right), 3.38$ (m, H-5'), 3.83 ( $d, J=11.5 \mathrm{~Hz}, \mathrm{H}-6$ 'a) and $3.63\left(d d, J=13.5 / 6.0 \mathrm{~Hz}, \mathrm{H}-6\right.$ 'b). ${ }^{13} \mathrm{C}$ NMR $\left(\mathrm{CD}_{3} \mathrm{OD}\right): \delta_{\mathrm{C}} 100.9$ (C-1), 151.7 (C-3), $113.7(\mathrm{C}-4), 44.0(\mathrm{C}-5)$, 76.0 (C-6), 129.6 (C-7), 151.6 (C-8), 46.5 (C-9), 61.9 (C-10), 175.3 (C-11), 100.3 (C-1'), 75.1 (C-2'), 78.5 (C3'), 71.7 (C-4'), 77.9 (C-5') and 62.9 (C-6').

7 $\beta$-Hydroxy-11-methylforsythide (3).Colorless amorphous powder. ${ }^{1} \mathrm{H}$ NMR $\left(\mathrm{CD}_{3} \mathrm{OD}\right): 5.44(d, J=4.0 \mathrm{~Hz}$, H-1), 7.40 (br s, H-3), 3.16 ( $m, \mathrm{H}-5), 1.57$ ( $m, \mathrm{H}-6 \mathrm{a}), 2.27$ (ddd, J=14.0/7.5/1.5 Hz, H-6b), 4.32 (br t, J=4.5 Hz, H-7), 2.57 ( $d d, J=9.5 / 4.5 \mathrm{~Hz}, \mathrm{H}-8), 2.74$ ( $d t, J=9.5 / 4.0 \mathrm{~Hz}, \mathrm{H}-9), 4.61$ ( $d, J=6.5 \mathrm{~Hz}, \mathrm{H}-1$ '), 3.20 ( $m$, H-2'), 3.34 ( $m$, H-3'),3.28 ( $m$, H-4'), 3.28 ( $m$, H-5'), 3.84 ( $d d, J=12.0 / 1.5$ Hz, H-6'a), 3.63 ( $d d, J=12.0 / 5.0$ Hz, H-6'b) and $3.67\left(s, \mathrm{OCH}_{3}\right) .{ }^{13} \mathrm{C}$ NMR $\left(\mathrm{CD}_{3} \mathrm{OD}\right): \delta_{\mathrm{C}} 97.5(\mathrm{C}-1), 152.2(\mathrm{C}-3), 113.9(\mathrm{C}-4), 31.9(\mathrm{C}-5), 42.6(\mathrm{C}-6), 73.5(\mathrm{C}-7)$, 54.4 (C-8), 43.8 (C-9), 180.4 (C-10), 169.5 (C-11), 100.1 (C-1'), 74.6 (C-2'), 78.4 (C-3'), 71.5 (C-4'), 77.9 (C5'), $62.9\left(\mathrm{C}-6\right.$ ') and $51.6\left(-\mathrm{OCH}_{3}\right)$.

Sodium loganate (4). Colorless amorphous powder. The ${ }^{1} \mathrm{H}$ and ${ }^{13} \mathrm{C}$ NMR data: See table 1.

\section{RESULTS AND DISCUSSION}

Examination of the chloroform and methanol extracts led to the isolation of four compounds. Of these, three were identified as $3 \beta, 6 \beta, 23-$ trihydroxyurs-12-en-28-oic acid (1) [5], sodium deacetylasperulosidate (2) [6], 7 $\beta$-hydroxy-11methylforsythide (3) [7] by comparison of their NMR spectral data with literature.

Compound (4) was isolated as a colorless amorphous powder. The molecular formula of (4) was determined as $\mathrm{C}_{16} \mathrm{H}_{23} \mathrm{O}_{10} \mathrm{Na}$ from the HR-ESIMS with the pseudomolecular ion peak at $\mathrm{m} / \mathrm{z}$ $399.1260[\mathrm{M}+\mathrm{H}]^{+}$(Calcd. for $\mathrm{C}_{17} \mathrm{H}_{23} \mathrm{O}_{11} \mathrm{Na}+\mathrm{H}$, 399.1266), and with the sodiated molecular ion peak at $m / z \quad 421.1076 \quad[\mathrm{M}+\mathrm{Na}]^{+} \quad$ (Calcd. for $\mathrm{C}_{17} \mathrm{H}_{23} \mathrm{O}_{11} \mathrm{Na}+\mathrm{Na}$, 421.1087). The ${ }^{13} \mathrm{CNMR}$ data
(Table 1) of (4) revealed 17 signals of a $\beta$-Dglucopyranosyliridoid. The $\beta$-glucopyranosyl moiety was proved by the anomeric proton signal at $\delta_{\mathrm{H}} 4.66$ $\left(1 \mathrm{H}, d, J=8.0 \mathrm{~Hz}, \mathrm{H}-1\right.$ ') corresponding to $\mathrm{C}-1$ ' $\left(\delta_{\mathrm{C}}\right.$ $99.8)$, as well as two signals at $\delta_{\mathrm{H}} 3.91(1 \mathrm{H}, d d, J=$ 12.0, $1.0 \mathrm{~Hz}, \mathrm{H}-6$ 'a) and 3.70 (1H, m, H-6'b) corresponding to $\mathrm{C}-6$ ' $\left(\delta_{\mathrm{C}} 62.7\right)$. The COSY along with HSQC and HMBC experiments supported the assignments of the protons and carbons belonging to the glucopyranosyl moiety. The presence of a iridoid skeleton was supported by the appearance of two olefinic carbon signals at $\delta_{\mathrm{C}} 146.5(\mathrm{C}-3)$ and 121.9 (C-4) together with an acetal carbon signal at $\delta_{\mathrm{C}} 96.7$ (C-1). The complete assignments of all proton and carbon resonances were relied on the results of COSY, HSQC and HMBC experiments. The 
chemical shift values of $\delta_{\mathrm{C}} 75.3$ and 42.5 were assigned for two methine carbons $\mathrm{C}-7$ and $\mathrm{C}-8$, respectively. The $\mathrm{HMBC}$ correlations between the methyl proton signal at $\delta_{\mathrm{H}} 1.10(3 \mathrm{H}, d, 7.0 \mathrm{~Hz}, \mathrm{H}-10)$ with carbon signals at $\delta_{\mathrm{C}} 75.3(\mathrm{C}-7), 42.5$ (C-8), 47.0 (C-9) confirmed the position of the methyl group at C-8. The position of the carborxyl group at C-4 was confirmed by the cross-peak of the methyl proton

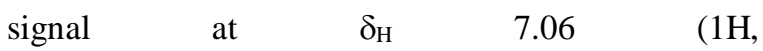
brs, $\mathrm{H}-3)$ and carbon signal at $\delta_{\mathrm{C}} 176.0(\mathrm{C}-11)$ in the HMBC spectrum. Based on the HMBC correlation between the anomeric proton signal at $\delta_{\mathrm{H}} 4.66(1 \mathrm{H}, d$, $J=8.0 \mathrm{~Hz}, \mathrm{H}-1$ ') with the acetal carbon $\mathrm{C}-1$ at $\delta_{\mathrm{C}}$ 96.7 the glucopyranosyl moiety attached to the was aglycon at $\mathrm{C}-1$.

To confirm the configuration of $\mathrm{C}-1$, compound (4) was acid hydrolyzed in order to measure the ${ }^{1} \mathrm{H}$ NMR spectrum of the aglycone and to compare this with literature data. However, the obtained amount of compound (4) was too little to hydrolyze. Therefore, based on the rule of 1,1'-disaccaride [8-10] by comparing the chemical shift values of the isolated iridoid glycoside $\left(\delta_{\mathrm{C}-1}, 99.8\right.$ in $\left.\mathrm{CD}_{3} \mathrm{OD}\right)$ with that of the $\beta$-D-glucopyranose $\left(\delta_{\mathrm{C}-1} 98.9\right.$ in pyridine- $\left.d_{5}\right)$ with $\Delta \delta_{\mathrm{C}}=0.9 \mathrm{ppm}$ less than $3.5 \mathrm{ppm}$, carbon $\mathrm{C}-1$ of compound (4) was proposed to possess the $S$ - configuration or the glycosidic linkage had a $\beta$ orientation. On the basis of above data of compound (4) and in comparison with published data of loganic acid [11] and of two diastereoisomers of loganin in the literature [12], we noticed that the chemical structure of (4) could be consistent with that of loganic acid. However, a careful comparison of the NMR data of compound (4) with those of loganic acid [11] showed complete differences at C-11 (+4.6 ppm), C-4 (+7.7 ppm), C-3 (-5.5 ppm), C-5 (+0.1 ppm), C-1 (-0.9 ppm) and H-3 (-0.4 ppm). The anionization effect was reported to cause the deshielding of the ${ }^{13} \mathrm{C}$ NMR chemical shift values of these carbons [13]. Literature reported that the chemical shift values of sodium salt of monotropein [13]were different from the corresponding ones of monotropein [13] at C-11 (+4.4 ppm), C-4 (+5.5 ppm), C-3 (-5.6 ppm), C-5 (+1.4 ppm), C-1 (-0.5 ppm) and $\mathrm{H}-3$ (-0.3 ppm). These altenations were also observed in spectral data of compound (4) and loganic acid[11]. This is an important proof to identify that (4) existed in the sodium salt. Therefore, the structure of compound (4) was determined as sodium loganate. To the best of our knowledge, (4) is a new compound.

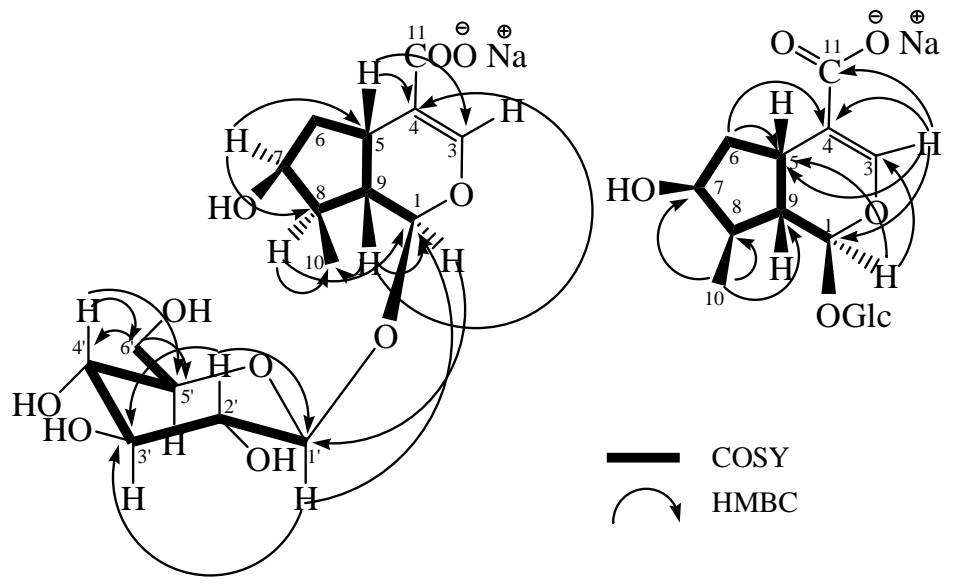

Fig. 3. Keys of COSY and HMBC of compound (4). 


\section{CONCLUSION}

From the whole plant of Borreria alata collected at Lam Dong province, Vietnam, four compounds $3 \beta, 6 \beta, 23$-trihydroxyurs-12-en-28-oic acid (1), sodium deacetylasperulosidate

(2), $\quad 7 \beta$-hydroxy-11-

methylforsythide (3) and sodium loganate (4) were isolated. These compounds were known for the first time in Borreria genus and sodium loganate (4) is a new compound.

Table 1. The comparison of NMR data of compound (4) with loganic acid and two diastereoisomers of loganin

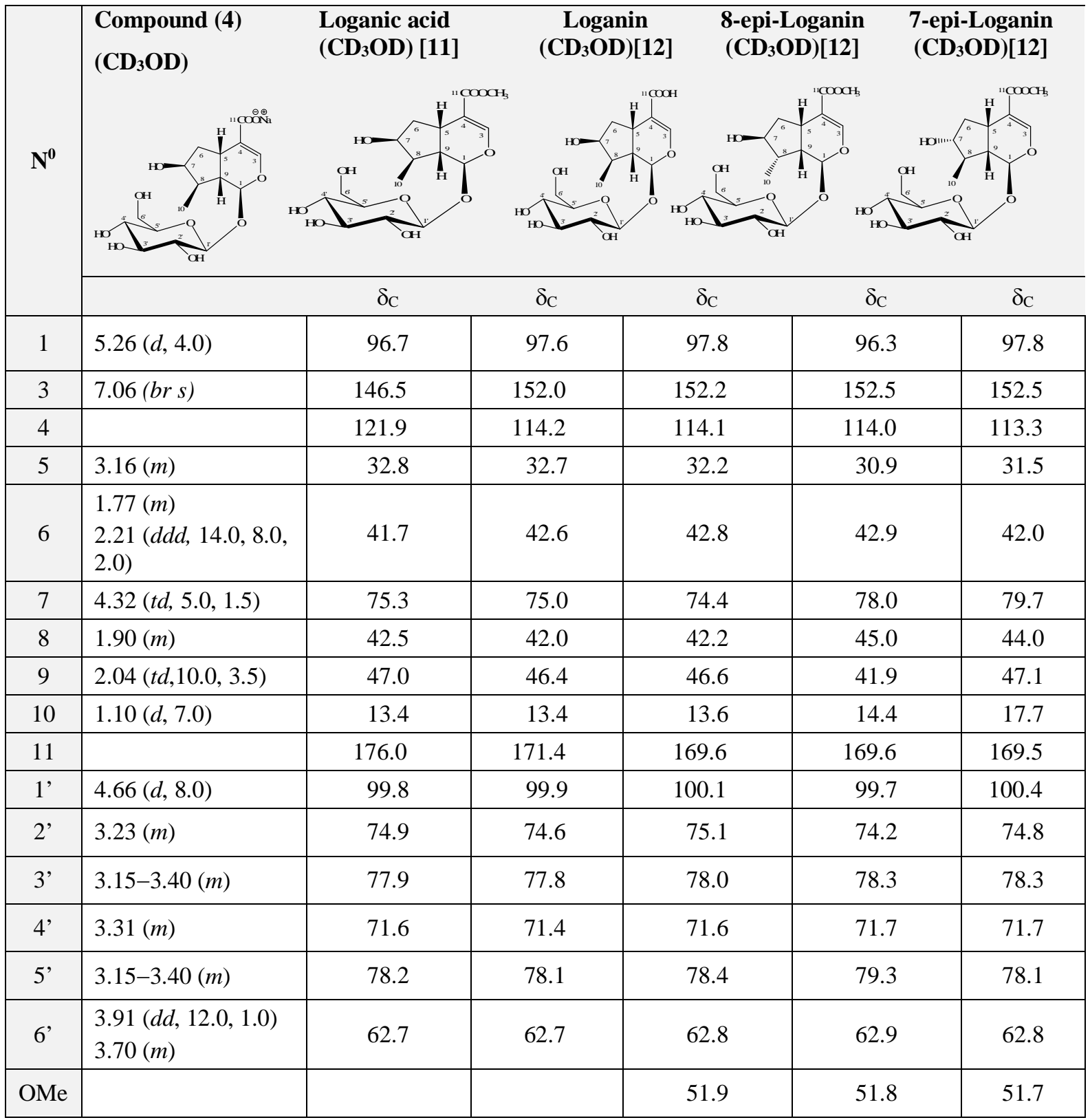




\section{Một hợp chất mới từ cây Borreria alata (Aubl.) DC (Họ Cà phê) ở Việt Nam}

\section{- Tô Cẩm Loan}

Trường Đại học An Giang

- Phạm Nguyễn Kim Tuyến

Trường Đại học Sài Gòn

- Nguyễn Kim Phi Phụng

Trường Đại học Khoa học Tự nhiên, ĐHQG-HCM

\section{TÓM TẮT}

Borreria thuộc ho Cà phê, là cây phổ biến ở vùng nhiệt đới và cận nhiệt Châu Mỹ, Châu Phi, Châu Âu và Châu Á. Nhũng nghiên cứu trước đây cho thấy cao chiết cũng nhu các hợp chất được cô lập tù các loài của chi Borreria có hoạt tính sinh hoc đa dạng nhu kháng viêm, chống $u$, kháng khuẩn, chống ôxy hóa.... Trong bài viết này, chúng tôi trình bày việc cô lập và dũ liệu phổ NMR của 4 hợp chất được cô lập tù cây
Borreria alata thu hái tại huyện Di Linh, tỉnh Lâm

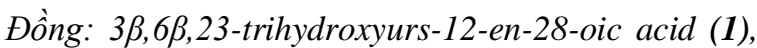
sodium deacetylasperulosidate (2), 73-hydroxy-11methylforsythide (3) và sodium loganate (4). Cấu trúc của các hơp chất được xác định thông qua phổ NMR, phổ khối và so sánh với các tài liệu đã công bố. Các hơp chất (1-3) lần đầu tiên được biết đến trong chi Borreria và (4) là một hợp chất mới.

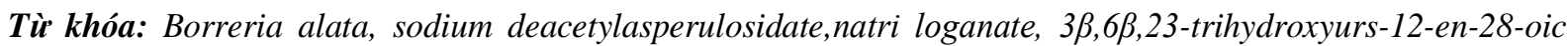
acid, 7 $\beta$-hydroxy-11-methylforsythide

\section{REFERENCES}

[1]. M.C. Lucia, C.F. Jesu., Júnior, Borreria and Spermacoce species (Rubiaceae): A review of their ethnomedicinal properties, chemical constituents, and biological activities, Pharmacognosy Review, 6, 11, $46-55$ (2012).

[2]. P.H. Ho, Vietnamese plants3, Young Publishing House, Ho Chi Minh City, Vietnam, 220 (2000).

[3]. N.P. Manandlar, An inventory of some vegetable drug resources of Makawanpur district Nepal, Fitoterapia, 66, 231-238 (1995).

[4]. K. Kamiya, Y. Fujita, Y. Saiki, E. Hanani, U. Mansur, T. Satake, Studies on the constitution of Indonesian Borreria latifolia, Heterocycles, 56, 537-544 (2002).

[5]. B. Ma, S. Liu, Y. Xie, Y. Kano, D. Yuan, Flavonol glycosides and triterpenes from the leaves of Uncaria rhynchophylla (Miq.) Jacks. Asian Journal of Traditional Medicines, 4, 3, 8591 (2009).

[6]. L.H.V. Long, V.T. Nga, N.P. Dam, M.A. Hung, T.D. Dung, T.T. Quang, N.K.P. Phung, Three new iridoid glucoside salts from Hedyotis tenelliflora growing in Vietnam, Natural Product Communications, 8, 11, 1507 (2013).

[7]. B. Dinda, S. Debnath, Y. Harigaya, Naturally occurring iridoids. A review, part 1, Chemical Pharmaceutical Bulletin, 55, 2, 198 (2007).

[8]. H. Matsuda, H. Shimoda, T. Uemura, T. Ueda, J. Yamahara, M. Yoshikawa, Chemical constituents from the leaves of Hydrangea macrophylla var. thunbergii (III): Absolute stereostructures of Hydramacrosides A and B, seco-iridoid glucoside complexes with inhibitory activity on histamine release, Chemical Pharmaceutical Bulletin, 47, 12, 1753-1758 (1999).

[9]. X. Haihui., M. Toshio, M. Hisashi, N. Seikou, M. Osamu, Y. Masayuki, Monoterpene constituents from Cistanche tubulosa - 
Chemical structures of Kankanosides A-E and Kankanol, Chemical Pharmaceutical Bulletin, 54, 5, 669-675 (2006).

[10].M. Nishizawa, S. Kodama, Y. Yamane, K. Kazano, S. Hatakeyama, H. Yamada, Synthesis and glycosylation shift of 1,1'-disaccharides. Chemical Pharmaceutical Bulletin, 42, 982-984 (1994).

[11].A.B. Christie, R.S. Frank, Iridoids an updated review. Part I, Journal of Natural Products, 53, 5, 1095 (1990).
[12].N. Kyowmi, O. Hideaki, Y. Kazu, 7-O-acetyl loganic acid from Alangium platanifolium var. Trilobum, Phytochemistry, 27, 1856-1858 (1988).

[13].C. Iavarone, A. Sen, C. Trogolo, Stefano VillaMollugoside, An iridoid glucoside from Galium mollugo, Phytochemistry, 22, 1, 175-178 (1983). 